\title{
Bullying Behaviors among University Students in Palestine
}

\author{
Hanani A* \\ Department of Public Health, An-Najah National University, Palestine
}

*Corresponding author: Ahmad Hanani, PhD, Department of Public Health, Faculty of Medicine and Health Sciences, An-Najah National University, Nablus, West Bank PO. Box 7, Palestine, Email: a.hanani@najah.edu

\section{Research Article}

Volume 5 Issue 2

Received Date: July 24, 2021

Published Date: September 27, 2021

DOI: $10.23880 /$ phoa-16000189

\section{Abstract}

Background: The problem of bullying in schools and universities is an issue of every nation around the globe. Researchers around the globe pointed out an abundance of negative impacts on students involved in bullying and require the focus and attention of adults to address and resolve bullying incidents among students.

Objectives: The purpose of the study investigating the prevalence rate of bullying and victimization and causes of bullying among university health sciences students in Palestine.

Method: The current survey design study was directed on samples were randomly and the total number of sample was 191 students (the male was 81 and the females were 110). Bullying was assessed by using a questionnaire developed from the literature by the researcher.

Result: As a result, it causes psychological disorders in the long-term, such as depression, anxiety, and aggression, whether it is directed toward the self, or toward others. In this study, the sample was randomly selected from one governorate in the West Bank of Palestine.

Conclusion: The study concludes that the common type of bullying behavior among male university students was physical and verbal bullying the highest among female university students. Also, the participants in the study mention that stress, jealousy, and revenge were from the common reasons for the bullying.

Keywords: Bullying; Victimization; University Students; Palestine

\section{Background}

Education system has the priority in all plans and development strategies in all over the world. They consider it as the most important of the national projects which aim to prepare human cadres, who can achieve goals and aspirations of their society. Student community is one of the most important elements of the school institution. It's the backbone of the society and its future promise to maintain and care for them. Also providing all conditions and possibilities necessary for their development and protecting them from harmful influences. Therefore, the integrated and balanced attention to the service of all students leads in general to the formation of a human personality compatible in terms of mental abilities, social and psychological, which needs all school and community coordination and efforts. Despite the considerable efforts made by schools in the area of education in particular. There are some negative phenomena that affect the effectiveness of the educational process and the ability of its members to achieve their goal [1].

Schools have been always viewed as institutions to transfer knowledge and culture to the future generation. It is a dynamic human system which aims at nurturing the mutual growth and understanding between children and adults. At schools, students are the core of the system. For 
their great importance, adequate information about pupils is necessary for any meaningful learning process in order to save teachers' effort and change learners in accordance with the set objectives, such factors that affect learning and teaching; including child growth, age heredity, interest, home and social effects and violence in school as well as school bullying, need to be addressed [2].

Studying problems of students, psychological and social adjustment are considered as an urgent and a necessary need. The accelerated aspects of economic, social, educational, technological and other changes have made life difficult and complex. This causes the appearance of many problems at all levels, including problems related to students' undesirable behavior. One of these problems which affecting students negatively is bullying, it affects the student himself and all his life aspects. Bullying is a phenomenon practiced by an individual on another person in his or her same age or younger. The latter is the riskiest. The consequences of this behavior on individuals, victims and bullies are very significant. Victims suffer from social isolation, rejection, persecution, harassment, irrelevance, low academic performance, and even more serious consequences for the future as some victims become even bullies. Bullies develop different aspects of social and criminal behavior, alcohol and drug abuse, and using weapons. Many people have an irrational idea of bullying which consider it as a normal behavior among children, and end automatically without the intervention of anyone. However, the renegades-bulliesvictims-victims-and bystanders-suffer from psychological and physical problems and difficulties that affect their lives and growth harmfully. Early awareness-raising is a most in order to stop bullying. There is an urgent need to teach students how to participate and communicate with others [3].

Bullying, based on research conducted in different countries, is a serious issue within schools from primary to high school in many western and eastern countries. Bullying as an aggressive behaviour has probably occurred as long as there have schools. However, until the pioneering work of Olweus in the 1970s, it had not received much attention. Shortly after Olweus working Scandinavian countries, interest in such a research spread in other countries [4]. Bullying is one of the violence phenomenons in its various forms, which may arise in riots, robbery, destroying property, and aggression toward teachers or students [5]. It is one of the most dangerous behaviours threatening the physical and mental health of students across a broad range of grades and school systems [6] Bullying is an aggressive behaviour characterized by three defining conditions: (a) negative or malicious behaviour intended to harm or distress, (b) behaviour repeated over time, and, most importantly, (c) a relationship in which there is an imbalance in strength or power between the parties involved American Psychological Association (APA) [7-9].

\section{Definitions}

Bullying behavior is to inflict harm on one or more individuals physically, psychologically, emotionally or verbally, and also includes the threat of physical or physical harm by means of arms and extortion, violation of civil rights, assault and beatings, gangs, attempted murder or threats [10].

Bullying described in relation to three main criteria [11].

- Aggressive behaviour or intentional harm doing

- Performed repeatedly and over time

- Takes place within the context of an interpersonal relationship characterized by an imbalance of power.

\section{Objectives}

The objectives of the current study were to answer the following questions:

- What is the frequency of bullying and victimization among male and female university health sciences students?

- What are the common types of bullying among university health sciences students in Palestine?

- What are the causes of peer bullying and victimization among university in Palestine according to point views of health sciences students?

\section{Methods}

The study used a survey design, and it provides sufficient information about the main study and what it was looking for. This Quantitative research conducted through a questionnaire and scale of "Bully-Victim Determination developed by Piskin \& Ayas was used for the Turkish students, whilst the adapted Arabic version of the instrument was used for the Palestinian students [12]. The tools measure the Bullying types and causes of bullied, victims, among university health science students in Palestine and the method which used was suitable to the purposes of the study. The researcher selected cluster randomly 191 students from medical profession department at Modern University College in Ramallah \& AlBireh governorate after received the approval letter from the ethical committee at the university college. The sample was 81 male students, and 110 female students.

\section{Results}

\section{Result of Question One}

What is the frequency of bullying and victimization among university health science students in Palestine? The 
next table shows frequencies and percentages of bullying and victimization among university health sciences students
(Table 1).

\begin{tabular}{|c|c|c|c|c|c|c|c|c|}
\hline & \multicolumn{4}{|c|}{ Victims } & \multicolumn{4}{c|}{ Bullies } \\
\hline \multirow{2}{*}{ Bullying Type } & \multicolumn{2}{|c|}{ Male } & \multicolumn{2}{|c|}{ Female } & \multicolumn{3}{c|}{ Male } & \multicolumn{2}{c|}{ Female } \\
\cline { 2 - 10 } & $\mathbf{n}$ & $\mathbf{\%}$ & $\mathbf{n}$ & $\mathbf{\%}$ & $\mathbf{n}$ & $\mathbf{\%}$ & $\mathbf{n}$ & $\mathbf{\%}$ \\
\hline Physical Bullying & 64 & 77 & 53 & 48 & 35 & 43 & 21 & 19 \\
\hline Verbal Bullying & 34 & 41 & 50 & 45 & 17 & 21 & 22 & 20 \\
\hline Social Bullying & 13 & 16 & 25 & 23 & 9 & 11 & 13 & 12 \\
\hline Rumors & 16 & 19.7 & 27 & 24.5 & 2 & 0.025 & 0 & 0 \\
\hline Damage to personal property & 17 & 20.9 & 18 & 16.4 & 5 & 0.06 & 1 & 0.009 \\
\hline Sexual Bullying & 26 & 32 & 21 & 19 & 25 & 31 & 0 & 0 \\
\hline
\end{tabular}

Table 1: Frequencies and Percentages of bullying and victimization among university health sciences students.

The results show that the prevalence rates of victimization among male and female university health sciences students were as following: according to physical bullying, male victims (77\%) and female victims (48\%). According to verbal bullying, male victims (41\%) and female victims (45\%). According to rumors, male victims (19.7\%) and female victims (24.5\%). According to social bullying, male victims (16\%) and female victims (23\%). According to damage to personal property, male victims $(20.9 \%)$ and female victims $(16.4 \%)$. According to sexual bullying, male victims (32\%) and female victims (19\%).

The results show that the prevalence rates of bullying among university students were as following: according to physical bullying, male bullies (43\%) and female bullies (19\%). According to verbal bullying, male bullies (21\%) and female bullies (20\%). According to social bullying, male bullies $(11 \%)$ and female bullies (12\%). According to sexual bullying, male bullies (32\%) but no female Bullies.

\section{Result of Question Two}

What are the common types of bullying among university health science students in Palestine?

The next table shows Frequencies and Percentages of types of bullying university students in Palestine (Table 2).

\begin{tabular}{|c|c|c|c|c|}
\hline \multicolumn{4}{|c|}{ Mictims } & \multicolumn{2}{c|}{ Female } \\
\hline & Type & $\%$ & Type & \% \\
\hline Common Level & Physical & 77 & Physical & 48 \\
\hline 1 & Verbal & 41 & Verbal & 45 \\
\hline 2 & Sexual & 32 & Rumors & 24.5 \\
\hline 3 & Property & 20.9 & Social & 23 \\
\hline 4 & Rumors & 19.7 & Sexual & 19 \\
\hline 6 & Social & 16 & Property & 16.4 \\
\hline
\end{tabular}

Table 2: Frequencies and Percentages of types of victimization among university health sciences students.

The results show that according to the common types of victimization among university health sciences students, the highest victimization type for male was physical victimization (77\%), the next was verbal victimization (41\%), then sexual victimization $(32 \%)$, and the lowest type was social victimization (16\%). According to the female, the highest victimization type was physical bullying (48\%), the next was verbal bullying $(45 \%)$, and then rumors victimization (24.5\%), the lowest common type was property (16.4\%) (Table 3). 


\begin{tabular}{|c|c|c|c|c|}
\hline \multicolumn{3}{|c|}{ Mullies } & \multicolumn{2}{c|}{ Female } \\
\hline & \multicolumn{2}{|c|}{ Male } & Type & \% \\
\hline Common level & Physical & 43 & Verbal & 20 \\
\hline 1 & Sexual & 31 & Physical & 19 \\
\hline 2 & Verbal & 21 & Social & 12 \\
\hline 4 & Social & 11 & Property & 1 \\
\hline 5 & Property & 6 & & \\
\hline 6 & Rumors & 2 & & \\
\hline
\end{tabular}

Table 3: Frequencies and Percentages of types of bullying among university health sciences students.

The results show that according to the common types of bullying among university health science students, the highest bullying type for male was physical victimization (43\%), the next was sexual bullying (31\%), then verbal bullying (21\%), and the lowest type was rumors (16\%). According to the female, the highest bullying type was verbal bullying (20\%), the next was physical bullying (19\%), then social bullying (12\%) (Table 4$)$.

\begin{tabular}{|c|c|c|c|}
\hline \multirow{2}{*}{ No. } & \multirow{2}{*}{ Phrase } & \multicolumn{2}{|c|}{ Bully } \\
\hline & & $\mathbf{n}$ & $\%$ \\
\hline 1 & Joking by hand & 50 & 0.26 \\
\hline 15 & Make fun of the way of talking or the accent & 36 & 0.19 \\
\hline 41 & Annoy by calling with sweet or honey .... etc. & 26 & 0.14 \\
\hline 4 & Take my place in the queue & 25 & 0.13 \\
\hline 22 & Ignore your presence & 18 & 0.09 \\
\hline 17 & Insult of use bad words & 18 & 0.09 \\
\hline 2 & Tickle to hassle, pull hair, pull ear & 16 & 0.08 \\
\hline 14 & $\begin{array}{l}\text { Make fun of the hair or the physical appearance or the cloths, the body shape or the skin color or the } \\
\text { teeth or the physical disabilities }\end{array}$ & 14 & 0.07 \\
\hline 23 & Stop talking to exclude you & 14 & 0.07 \\
\hline 40 & Use sexual hints through the face or the body (lick the lips or send hints by eyes or hands etc.) & 12 & 0.06 \\
\hline 19 & Threatening & 10 & 0.05 \\
\hline 16 & Make fun of the name, family name, or call you with a nickname you hate as humiliation & 8 & 0.04 \\
\hline 18 & Make you embarrassed or angry, or make you sad or cry for different reasons & 8 & 0.04 \\
\hline 49 & Write or draw on the wall of the toilets by using the names of people with sexual overtones & 8 & 0.04 \\
\hline 3 & Place objects on the chair when you sit & 6 & 0.03 \\
\hline 5 & Force to leave the Playground when playing & 6 & 0.03 \\
\hline 7 & Push or poke, bend or flex the hand, obstruction and falling on the ground & 6 & 0.03 \\
\hline 9 & Push by shoulders, hit by elbow, collision in purpose & 6 & 0.03 \\
\hline 21 & Get you out of the group and leave you alone & 6 & 0.03 \\
\hline 20 & Don't let you to participate in events or activities of the university & 4 & 0.02 \\
\hline 35 & Scribbles on the books and notebooks and write bad words & 4 & 0.02 \\
\hline 44 & Joking by touching sensitive places in the body and unacceptable to be touched & 4 & 0.02 \\
\hline 46 & Joking with annoying words containing sex & 4 & 0.02 \\
\hline 8 & Throwing objects to harm and annoy & 2 & 0.01 \\
\hline 24 & Don't allow others to talk to him or be friends with them & 2 & 0.01 \\
\hline
\end{tabular}




\begin{tabular}{|c|c|c|c|}
\hline 26 & Discrediting and spreading rumors among students & 2 & 0.01 \\
\hline 28 & Writing bad things about him in different places & 2 & 0.01 \\
\hline 31 & Take his stuff or money by force & 2 & 0.01 \\
\hline 32 & Force him his things from the cafeteria & 2 & 0.01 \\
\hline 33 & Steal his money or stuff & 2 & 0.01 \\
\hline 38 & Don't return his stuff that he borrowed & 2 & 0.01 \\
\hline 42 & Try to kiss or touch with an intention for sex out of his control & 2 & 0.01 \\
\hline 45 & Nicknaming with annoying names containing sex & 2 & 0.01 \\
\hline
\end{tabular}

Table 4: Frequencies and percentages for phrases for bullying.

The results of the table above show that the highest five phrases as bullies were: joking by hand (26\%), make fun of the way of talking or the accent (19\%), annoy by calling with sweet or honey .... etc. (14\%), take my place in the queue (13\%), and ignore your presence (9\%). From the other hand, the lowest phrases as bullies were: Try to kiss or touch with an intention for sex out of his control (1\%), and nicknaming with annoying names containing sex (1\%).

\section{Result of Question Three}

What are the causes of bullying and victimization among university health sciences students in Palestine according to point views of students?

The next table show Frequencies answers for the causes of bullying and victimization among university health sciences students in Palestine according to point views of students (Table 5).

\begin{tabular}{|c|c|}
\hline No & In your Opinion, why do Some Students Practice Bullying? \\
\hline 1 & Stress \\
\hline 2 & Because of their Jealousy \\
\hline 3 & To show their strength in front of others \\
\hline 4 & Due to their enjoyment of hurting others \\
\hline 5 & Fue to being exposed to bullying by other students \\
\hline 6 & For being exposed to bullying in their own homes \\
\hline 7 & Ls a result of watching movies and cinematic films containing such violent snapshots \\
\hline 8 & Lack of aweness toward to this phenomenon \\
\hline 9 & Psychological problems \\
\hline 10 & Related to or working with one of the security systems \\
\hline 11 & Absent or ineffective of punishment rules \\
\hline 12 & Low self-esteem \\
\hline 13 & Bad relationship \\
\hline 14 & Imitating behaviors faced at home, at street, and from social media and others \\
\hline 15 & Domestic violence \\
\hline 16 & Authorities parenting style \\
\hline 17 & \\
\hline 18 & \\
\hline
\end{tabular}

Table 5: Frequencies answers for the causes of bullying and victimization.

\section{Discussion}

This research was carried out with the purpose of investigating the prevalence rate of bullying and victimization and causes of bullying among the sample of university students in Palestine. Towards this end, the following sections discuss the findings of the analyses made. When the question on the frequency of bullying among male and female students was examined, the results showed a statistically significant gender difference in the percentage of victims and 
the bullies. Specifically, it was observed that the percentage of victims was generally higher among male students compared to their female counterparts. Similarly, the percentage of bullies was generally higher among male students than their female counterparts. This finding could be explained in terms of traditional gender role theory that always seeks to associate masculinity with fearlessness and one's ability to behave aggressively. In a very conservative society such as the West Bank, male children undoubtedly are likely to be socialized into accepting such traits as physical and mental toughness and thus will like to demonstrate them on those they find weaker. This is even evident in their responses to the question on the causes of bullying as most of them answered that it is to show one's physical strength. Other previous researchers have equally corroborated this finding. For instance, in a study by Antill, Cunningham, Russell, and Thompson in Australia, the researchers concluded that those males who are unable to live up to the stereotype of physical and mental toughness are considered desirable qualities for Australian males, fear having their masculinity questioned. As a result, they try to act tough or sometimes tougher than their peers in order to prove their masculinity. This is why many of them end up as bullies. In a similar past study, [13] also reported that males generally bully more than females that their own male colleagues mainly bully them and those females are equally bullied by males and females.

The current research concludes with the study of Hanani A [12], who said that the bully, who sees the acceptance and approval of his family members for violent and aggressive behavior associated with his sex, sees himself and conceives through his family's perception of him. The friends and peers of the bully are greatly influencing the formation of a bullying image of itself. Where his self-esteem and respect depend on what they consider and approve of and favour violent behavior on the victim. As much his relations with friends saturated, as much as the acceptability, from them and the more self-appreciated. This acceptance and recognition by peers and friends for his socially unacceptable behavior will gradually form part of his vision of himself and his entity, so he will try to adapt as much as he can.

The study concluded that the credence voices of students in the universities of Palestine sought to uncover not only student perspectives about bullying but also to determine these perceptions regarding bullying. And, Impact of the political, military, and economic blockade on the Palestinian territories impacted the psychological aspects of the Palestinian youth, especially those which creating stressful conditions affecting all aspects of their life. Where the participants in the study mentioned that the first common answers about the reasons for the bullying in Palestine were stress, jealousy, and revenge. Concluded that common type of bullying among male university students was physical and verbal bullying the highest among female university students.

\section{Acknowledgements}

The author highly appreciates all colleagues who helped in distribution and allowing to do the questionnaire among the targeted students.

\section{Funding}

The author covered the research expenses by themselves and they did not receive funds for this work.

\section{Conflicts of Interest}

The author declares no conflicts of interest regarding the publication of this paper.

\section{References}

1. Al-Qhatani N (2008) Bullying among intermediate school students in Riyadh city: survey study and a proposal intervention program suitable to school environment in Saudi Arabian. Unpublished dissertation, King Saud University, the Kingdom Saudi Arabia.

2. Omoniyi M (2013) Bullying in schools: Psychological implications and counselling interventions. Journal of Education and Practice 4(18): 70-78.

3. Sbehin A, Judgea M (2013) Bullying behavior in children and adolescents. $1^{\text {st }}$ (Edn.), Naif Arab University for Security Sciences.

4. Piskin M (2002) School Bullying: Definition, types, related factors, and strategies to prevent bullying problems, Educational sciences: Theory and Practice 2(2): 531-561.

5. Awaidat A (1997) Impact of family patterns on the nature of behavioural deviations among students in grades 8-10, Majalet Alderasat Altarbaweih 24(1): 83-101.

6. Evers K, Prochaska J, Marter D, Johnson J, Prochaska J (2007) Transtheoretical-based bullying prevention effectiveness trials in middle schools and high schools. Educational Research 49(4): 397-414.

7. Gini G (2004) Bullying in Italian schools: An overview of intervention programmes. School Psychology International 25(1): 106-116.

8. Nansel TR, Overpeck M, Pilla RS, Ruan WJ, SimonsMorton B, et al. (2001) Bullying behaviors among US youth: Prevalence and association with psychosocial 
adjustment. JAMA 285(16): 2094-2100.

9. Olweus D, Solberg C (1998) Bullying among children and young people. Information and guidance for parents.

10. Omoniyi M (2013) Bullying in schools: Psychological implications and counseling interventions. Journal of Education and Practice 18(4): 70-78.

11. Piskin M (2010) Examination of peer bullying among primary and middle school children in Ankara. Journal of Education and Science 35(156): 175-189.

12. Hanani A (2018) Investigation of peer bullying among secondary school students in Palestine. Unpublished Doctoral Dissertation, Ankara University.

13. Farrington DP (1993) Understanding and preventing bullying. Crime and Justice 17, pp: 381-458. 